DOI

\title{
ДОСЛІДЖЕННЯ СТРУКТУРНИХ ЗМІН У ШЛУНОЧКАХ ЛЕГЕНЕВОГО СЕРЦЯ ПОЛЯРИЗАЦІЙНОЮ МІКРОСКОПІЄЮ
}

\author{
๑О. Б. Слабий, М. С. Гнатюк
}

ДВНз «Тернопільський державний медичний університет імені І. Я. Горбачевського МОз України»

РЕЗЮМЕ. В експерименті встановлено, що пострезекційна артеріальна легенева гіпертензія призводить до розвитку легеневого серця і вираженої структурної перебудови шлуночків серця. Остання характеризується гіпертрофією кардіоміоцитів, їх ядер, дистрофією, некробіозом клітин, тканин, інфільтративними та склеротичними процесами. Поляризаційна мікроскопія адекватно відображає структурні зміни міофібрилярного апарату у вигляді контрактурних ушкоджень кардіоміоцитів, осередків міоцитолізу, зернисто-глибчастого розпаду, дисоціації серцевих м'язових волокон. Виявлені морфологічні зміни домінували у правому шлуночку декомпенсованого легеневого серця.

КлючОВІ СлОВА: легеневе серце, шлуночки, поляризаційна мікроскопія.

Вступ. В останні роки клініцисти та морфологи все частіше почали цікавитися легеневим серцем. Ця проблема набуває все більшого значення у зв'язку зі зростанням числа хронічних обструктивних захворювань легень, хронічних форм туберкульозу, професійних патологій легень, при яких основною причиною втрати працездатності і скорочення життя хворих $\epsilon$ декомпенсація хронічного легеневого серця [1-3]. Патогенез хронічного легеневого серця складний і досить багатогранний, що значною мірою ускладнює своєчасну діагностику легеневої артеріальної гіпертензії та хронічного легеневого серця $[2,4]$. При дослідженні патологічних процесів, які виникають у міокарді легеневого серця, застосування поляризаційної мікроскопії, поряд зі звичайними гістологічними, гістохімічними, електронно-мікроскопічними методами, дозволить отримати більш повну та адекватну інформацію про стан міофібрилярного апарату, який досить чутливий до різних негативних ендогенних та екзогенних впливів [5]. Варто також зазначити, що експериментальні морфологічні дослідження дають можливість отримати цінний матеріал для об'єктивного встановлення та уточнення механізмів морфогенезу ушкоджених органів і визначення їх адаптаційних резервів та можливостей коригуючих методів.

Мета дослідження. Вивчення особливостей структурних змін шлуночків легеневого серця за допомогою поляризаційної мікроскопії.

Матеріал і методи дослідження. Комплексом морфологічних методів досліджені особливості структурної перебудови лівого і правого шлуночків серця 38 білих статевозрілих щурівсамців, які були поділені на 3 групи: 1 група включала 15 інтактних здорових дослідних тварин (контрольна), що перебували у звичайних умовах віварію, 2 - 15 щурів з артеріальною гіпертензією у малому колі кровообігу і компенсованим легеневим серцем, 3-8 експериментальних тварин 3 легеневою артеріальною гіпертензією і декомпенсованим легеневим серцем. Останнє підтверджувалося задишкою, синюшністю слизових оболонок, гідротораксом, гідроперикардом, застійними явищами в органах великого кола кровообігу. Пострезекційну легеневу артеріальну гіпертензію і легеневе серце моделювали шляхом виконання у щурів правосторонньої пульмонектомії [6]. Оперативні втручання виконували в умовах тіопенталового наркозу з дотриманням правил асептики та антисептики. Через 3 місяці від початку досліду здійснювали евтаназію щурів кровопусканням в умовах тіопенталового наркозу. Серце розрізали за методикою Г. Г. Автанділова, проводили окреме зважування камер серця, їх планіметрію [7]. Усі маніпуляції та евтаназію щурів проводили з дотриманням принципів роботи з експериментальними тваринами. Зі шлуночків серця вирізали шматочки, які фіксували у $10 \%$ нейтральному розчині формаліну і після відповідного проведення через етилові спирти зростаючої концентрації поміщали у парафін. Мікротомні зрізи товщиною 5-7 мкм фарбували гематоксиліном-еозином, за ван-Гізон, Гейденгайном, Маллорі, Вейгертом, толуїдиновим синім, проводили імпрегнацію сріблом [8]. Гістологічні мікропрепарати шлуночків серця досліджували із застосуванням світлової та поляризаційної мікроскопії за допомогою мікроскопів МБД-6 та МБД-15.

Результати й обговорення. Окремим зважуванням та планіметрією камер серця встановлено, що через 3 місяці після правосторонньої пульмонектомії зростала маса частин серця та їхні просторові характеристики з домінуванням гіпертрофії та дилатації правого шлуночка. Отримані результати свідчили про розвиток пострезекційної артеріальної легеневої гіпертензії та легеневого серця $[3,9]$. 
Огляди літератури, оригінальні дослідження, погляд на проблему

Дослідження гістологічних мікропрепаратів шлуночків неушкодженого серця білих щурів показало, що їхня гістологічна структура була стабільною. При цьому в міокарді спостерігався незначний, а інколи помірно виражений набряк, що деякі дослідники пов'язують з методами евтаназії тварин. У поляризованому світлі відмічалася чітка поперечна посмугованість міофібрил у серцевих м'язових волокнах.

При світлооптичному дослідженні мікропрепаратів шлуночків серця дослідних тварин (2, 3 групи спостережень) виявляли виражені міжм'язові та перивазальні набряки, потовщення стінки вінцевих артерій з плазматичним просяканням, венозне повнокров'я з явищами стазу, сладж у венозних структурах гемомікроциркуляторного русла, гіпертрофію кардіоміоцитів, їх ядер, осередки дистрофії, некробіозу серцевих м'язових клітин, ендотеліоцитів, стромальних структур, вогнищеві інфільтративні та склеротичні процеси. При цьому варто зазначити, що домінували виявлені морфологічні зміни у правому шлуночку декомпенсованого серця.

Вивченням гістологічних мікропрепаратів шлуночків серця білих щурів 2 та 3 експериментальних груп у поляризованому світлі встановлено, що у міокарді лівого і правого шлуночків спостерігалися різної вираженості контрактурні пошкодження кардіоміоцитів. Відмічалося посилення анізотропії дисків А, вкорочення ізотропних дисків, а також осередки внутрішньоклытинного міоцитолізу. Останній місцями розповсюджувався та захоплював великі осередки м'язових волокон. При міоцитолізі м'язові волокна набряклі, зміненої форми, в ушкоджених ділянках відсутні міофібрили. Осередки міоцитолізу значно слабше зв'язують як аніонні, так і катіонні барвники. Прогресування міоцитолізу може переходити у колікваційний некроз. Виникає лізис ядра, сарколема потовщується та колагенізується за рахунок сполучнотканинних клітин, які локалізовані навколо вказаного вогнища (рис. 1). На місці загиблої клітини залишаються колагенові волокна. В основі процесу міоцитолізу лежить дезагрегація саркоплазматичних та міофібрилярних структур, а напівпроникна мембрана (сарколема) зберігається. Цим і пояснюється виникнення набряку в ушкодженому осередку серцевого м'язового волокна.

Відмічали також формування тріщин та дисоціацію м'язових волокон. Необхідно вказати, що контрактури міофібрил I - II ступенів були обумовлені в основному збільшенням анізотропії дисків А і різною вираженістю вкороченості ізотропних дисків. Зустрічалися також м'язові сегменти із суцільною анізотропією міофібрил. Відомо, що суцільна анізотропія виникає при злитті дисків А між собою. У деяких ділянках міокарда спостерігали розпад міофібрил на окремі різних розмірів грудочки. Місцями морфологічні зміни в міокарді лівого та правого шлуночків дослідних тварин 2 та 3 груп виявлялися у вигляді фрагментації кардіоміоцитів, мала місце також хвилеподібна деформація м'язових волокон у поєднанні із зернисто-глибчастим розпадом міофібрил (рис. 2, 3).

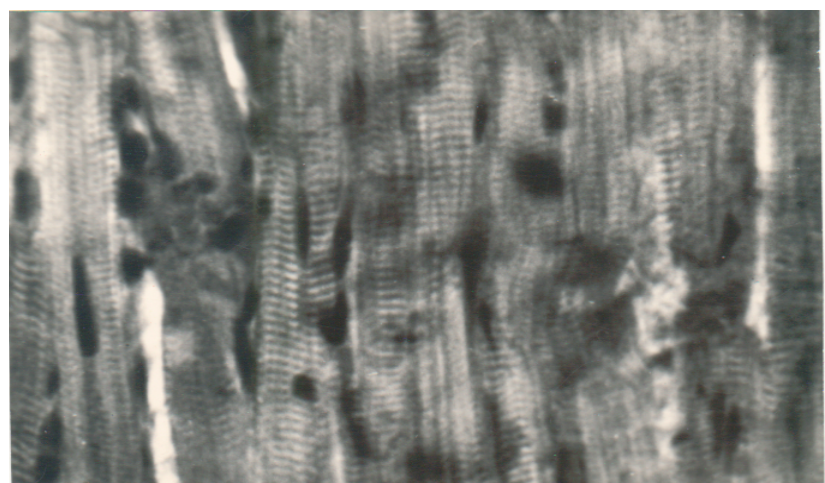

Рис. 1. Контрактури міофібрил І-ІІ ступенів, осередки внутрішньоклітинного міоцитолізу у лівому шлуночку компенсованого легеневого серця. Забарвлення гематоксиліном-еозином. Поляризоване світло. 36.: х 400.

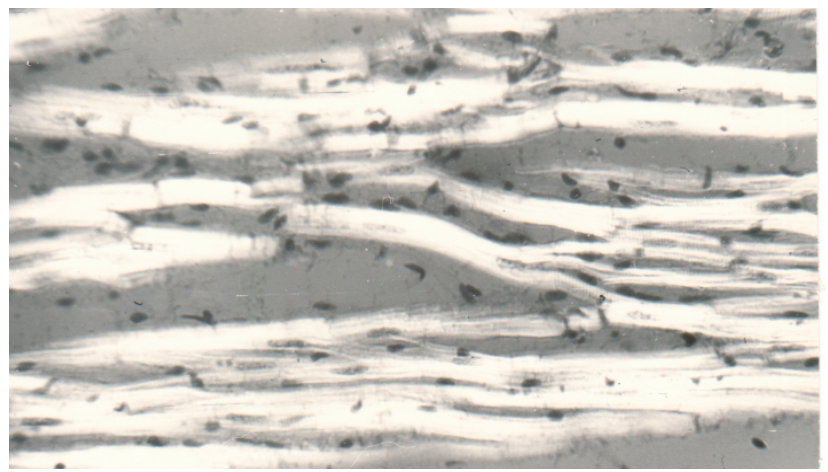

Рис. 2. Осередки суцільної анізотропії міофібрил, фрагментація серцевих м'язових волокон у правому шлуночку компенсованого легеневого серця. Забарвлення гематоксиліном-еозином. Поляризоване світло. 36.: $\times 125$.



Рис. 3. Контрактури, зернисто-глибчастий розпад міофібрил, фрагментація серцевих м'язових волокон у правому шлуночку декомпенсованого легеневого серця. Забарвлення гематоксиліном-еозином. Поляризоване світло. 36.: х 125. 
Огляди літератури, оригінальні дослідження, погляд на проблему

Описані вище структурні зміни міокарда, які виявлялися у поляризованому світлі, домінували у правому шлуночку декомпенсованого легеневого серця, тобто у 3 групі спостережень. Контрактурні ушкодження міофібрилярного апарату кардіоміоцитів розвиваються поступово. Перші ознаки дистрофії кардіоміоцитів пов'язані із зміною міофібрил, яка характеризується посиленням анізотропії. Виникають вкорочення ізотропних дисків і злиття анізотропних дисків з утворенням суцільних конгломератів та наступним їх розпадом. Варто зазначити, що вказана послідовність ушкоджень фібрилярного апарату кардіоміоцитів має місце в гіперфункціонуючому гіпертрофованому міокарді $[10,11]$, тобто у легеневому серці. Наведене свідчить, що вивчення мікропрепаратів ушкодженого міокарда в поляризованому світлі дозволяє у динаміці прослідкувати генез вогнищевих дистрофічних, некробіотичних та склеротичних процесів, тобто суттєво розширити сучасні уявлення про патоморфогенез легеневого серця.

Деякі дослідники стверджують, що виявлені структурні зміни в шлуночках легеневого серця можуть призводити до порушень ритму та фібриляції шлуночків серця $[9,10]$. Виражені перева- жаючі патогістологічні зміни у правому шлуночку легеневого серця свідчать, що цей відділ міокарда при пострезекційній легеневій гіпертензії найбільш функціонально перевантажений і більшою мірою структурно змінений, порівняно з лівим шлуночком.

Висновки. 1. Правостороння пульмонектомія призводить до розвитку легеневого серця, вираженої структурної перебудови шлуночків серця, яка характеризується гіпертрофією, контрактурними пошкодженнями кардіоміоцитів, осередками міоцитолізу, глибчастого розпаду, дисоціацією м'язових волокон, дистрофією, некробіозом клітин, тканин, інфільтративними та склеротичними процесами.

2. Більш виражені структурні зміни міокарда домінують у правому шлуночку декомпенсованого легеневого серця.

Перспективи подальших досліджень. Детальне усестороннє дослідження особливостей структурних змін у шлуночках легеневого серця за допомогою поляризаційної мікроскопії $\epsilon$ перспективним з метою їх врахування при діагностиці, корекції та профілактиці ускладнень пострезекційної легеневої артеріальної гіпертензії.

\section{ЛІТЕРАТУРА}

1. Амосова К. М. Клінічний перебіг та стан міокарда з хронічним легеневим серцем унаслідок хронічної обструктивної патології легень залежно від наявності легеневої гіпертензії / К. М. Амосова, Л. Ф. Конопльова, І. Д. Мазур // Серце і судини. - 2009. - № 2. - С. 48-52.

2. Коноплева Л. Ф. Хроническое легочное сердце: проблемы классификации, диагностики и лечения / Л. Ф. Коноплева // Здоров'я України. - 2011. - № 1 (13). С. 24-26.

3. Норейко Б. В. Хроническоре легочное сердце / Б. В. Норейко, С. Б. Норейко // Новости медицины и фармации. - 2011. - № 9 (364). - С. 14-17.

4. Макаров М. А. Роль дисфункции эндотелия и ригидности артерий в патогенезе хронической обструктивной болезни легких / М. А. Макаров, С. Н. Авдеев, А. Г. Чучалин // Терапевтический архив. - 2012. - № 3. C. $74-80$.

5. Садовников В. А. Моделирование состояния дезинтеграции сердца предельными загрузками / В. А. Садовников, А. Н. Баранов // Морфология. - 1998. T. 113, № 3. - C. 104-106.
6. Татарчук Л. В. Морфометричний аналіз ремодельованих камер серця після пульмонектомії / Л. В. Татарчук // Здобутки клінічної та експериментальної медицини. - 2011. - № 2 (15). - С. 123-126.

7. Автандилов Г. Г. Основы количественной патологической анатомии / Г. Г. Автандилов. - М. : Медицина, 2002. -268 c.

8. Горальський Л. П. Основи гістологічної техніки і морфофункціональні методи дослідження у нормі та при патології / Л. П. Горальський, В. Т. Хомич, О. І. Кононський. - Житомир : Полісся, 2011. - 288 с.

9. Barnes P. Y. Chronic obstructive pulmonary disease molecular and cellular mechanisms / P. Y. Barnes, D. Shapiro, R. A. Pamwels // Eur Respirat. J. - 2003. Vol. 22. - P. 672-678.

10. Cowie M. Survival of patients with a new diagnosis of heart failure: a population based study / M. Covie, D. Wood, A. Coats // Heart. - 2000. - Vol. 83. - P. 505-510.

11. Simonnean G. Clinical classification of pulmonary hypertension / J. Simonnean, N. Galie, L. Rubin // Y. Am. Cell. Cardiol. - 2004. - № 12. - P. 55-125. 
Огляди літератури, оригінальні дослідження, погляд на проблему

INVESTIGATION OF STRUCTURAL CHANGES IN VENTRICLES OF COR PULMONLE BY POLARIZATION MICROSCOPY

@O. B. Slabyi, M. S. Hnatiuk

\section{Horbachevsky Ternopil State Medical University}

SUMMARY. In experimental condition there was found that post-resection arterial pulmonary hypertension leads to the development of pulmonary heart and severe structural reconstruction left and right ventricles. The latter is characterized by hypertrophy of cardiomyocytes, their nuclei, dystrophic and necrobiotic changes of cells and tissues, infitration and sclerotic processes. Polarization microscopy adequate reflect structural changes of myofibrillar structures in form contracture injures of cardiomyocytes, foci of myocytolyses, cracs and dissociation of cardiac muscle fibers, foci of granular-clumpy decay. Revealed morphological changes in the right ventricles dominated decompensatory pulmonary heart.

KEY WORDS: cor pulmonale, ventricles, polarization microscopy. 